\title{
LABOR LAW: IMPLEMENTATION OF CONGRESSIONALLY DECLARED NATIONAL LABOR POLICY PRECLUDES INVOCATION OF DOCTRINE OF PRE-EMPTION.
}

The Supreme Court has held that a ruling by the General Gounsel of the National Labor Relations Board that no "employees," as defined by the National Labor Relations Act, were involved in a labor dispute precluded the possibility that picketing activities arising out of the dispute constituted a violation of section $\delta(b)(4)(B)$ of the act. In this circumstance, the Court held that the pre-emption doctrine should not be invoked when its application will tend to thwart federally established labor relations policy.

A FTER THE passage of the National Labor Relations Act ${ }^{1}$ in 1935, and especially in the period following its amendment by the Labor Management Relations Act $^{2}$ in 1947, federal-state conflict in controlling union activity has become a matter of critical concern. ${ }^{3}$

${ }^{1}$ (Wagner Act), 49 Stat. 449 (1935) (codified in scattered sections of 29 U.S.C.).

${ }^{2}$ (Taft-Hartley Act), 61 Stat. 136 (1947) (codified in scattered sections of 29 U.S.C.).

The primary purposes of the LMRA were to protect employee self-determination and to curb much union activity that previously had been left to the play of economic forces and to state control. See Meltzer, The Supreme Court, Congress, and State Jurisdiction Over Labor Relations: I, 59 CoLUM. L. REv, 6, 8 (1959). Although state regulation of employer labor practices has diminished radically since the enactment of the NLRA, there is still much state legislation governing union activities. Thus, the advent of federal regulation where state power had previously predominated intensified the problem of federalism and catalyzed the rise of pre-emption to the place of eminence which it holds in labor law today.

${ }^{3}$ The federalism aspect of labor law has been a prolific subject for treatment by the commentators. See, e.g., Cox, Federalism in the Law of Labor Relations, 67 HARv. L. Rev. 1297 (1954); Di Fede, Problems of Federal-State Jurisdiction in LaborManagement Disputes, N.Y.U. IlTH CONF. ON LABOR 85 (1958); Fanning, The "NoMan's-Land" and the National Labor Relations Board's Jurisdictional Policies, 8 GATHOLIC U.L. REv. I (1959); Forkosch, Jurisdiction and Its Impact on State Powers, 16 OHı ST. L.J. 301 (1955); Gregory, Federal or State Control of Concerted Union Activities, 46 VA. L. REv. 539 (1960); Hanley, Federal-State Jurisdiction in Labor's No Man's Land: 1960, 48 GEO. L.J. 709 (1960); Hardbeck, Federal-State Jurisdictional Issues and Policies Under the New Labor Law, 12 LAB. L.J. 99 (1961); Hays, Federalism and Labor Relations in the United States, 102 U. PA. L. REv. 959 (1954); Hays, State Courts and Federal Preemption, 23 Mo. L. Rev. 373 (1958); Isaacson, Federal Pre-emption Under the Taft-Hartley Act, II IND. \& LAB. Ren. REv. 391 (1958); Kadish \& Degnan, Some Light in the Twilight Zone, 5 UTAH. L. Rev. 336 (1957); McCoid, Notes on a "G-String": A Study of the "No Man's Land" of Labor Law, 44 MnN. L. REv. 205 (1959); Meltzer, The Supreme Court, Congress, and State Jurisdiction Over Labor Relations: L, 59 CoLuM. L. REv. 6 (1959); Michelman, State Power to Govern Concerted Employee Activities, 74 Harv. L. Rev. 64I (1961); Tobriner \& Grodin, Taft-Hartley Pre-emption in the Area of NLRB Inaction, 44 
The Supreme Court has struggled repeatedly to develop guidelines for ascertaining the extent to which Congress, by exercising its legislative power under the commerce clause, ${ }^{4}$ has precluded states from regulating labor relations. ${ }^{5}$ The most recent Court decision to consider the degree of state action which is consonant with congressional designs is Hanna Mining Co. v. District 2, Marine Eng'rs Beneficial Ass $n .^{6}$ The unusual fact situation involved occasioned a re-examination and a further clarification of the various factors which will render a state powerless to regulate a labor dispute.

Hanna Mining Company ("Hanna") had a collective bargaining agreement with District 2, Marine Engineers Beneficial Association ("MEBA") covering its licensed marine engineers. After the contract had terminated and while the parties were negotiating a new agreement, a majority of the engineers informed Hanna that they no longer desired representation by MEBA. When Hanna refused to bargain further until MEBA had established its majority status, the union retaliated by picketing Hanna's ships at various Great Lakes ports. Hanna immediately filed a petition with the NLRB requesting a representation election. The Board ruled that no representation question existed, for Hanna's engineers were not "employees"7 but "supervisors,"8 and a bargaining unit comprised

CalrF. L. REv. 663 (1956); Turnbull, Federal-State Jurisdictional Problems, 7 LAB. L.J. 5 (1956); Woll \& Antoine, Who Goes There?: Recent Moves Along the FederalState Front in Labor Law, 11 SYRACUSE L. REv. 1 (1959).

- U.S. Consr. art. I, $\S 8(3)$. "The Congress shall have Power . . . To regulate Commerce ... among the several States...."

The commerce clause is the head of power upon which Congress has bottomed federal labor legislation. See, e.g., NLRB v. Jones \& Laughlin Steel Corp., 301 U.S. 1, 31-46 (1937), upholding the NLRA on this basis.

Although pre-emption has been the pivotal issue in numerous Supreme Court decisions, the Court has rather infrequently expounded upon the doctrine in any general sense. Instead it has chosen to enlighten the "penumbral area" in which state regulation is permissible "by the course of litigation," Weber v. AnheuserBusch, Inc., 348 U.S. 468, 480-81 (1955), with each decision being concerned almost exclusively with the narrow, specific fact situation in the case before the Court. There have been notable exceptions to this principle, however, in which the Court has developed pre-emption guidelines. See, e.g., San Diego Bldg. Trades Council v. Garmon, 359 U.S. 236 (1959); International Ass'n of Machinists v. Gonzales, 356 U.S. 617 (1958); Guss v. Utah Labor Relations Bd., 353 U.S. 1 (1957); Weber v. AnheuserBusch, Inc., 348 U.S. 468 (1955); Garner v. Teamsters Union, 346 U.S. 485 (1953); International Union, UAW v. Wisconsin Employment Relations Bd., 336 U.S. 245 (1949) (the Briggs-Stratton case); Hill v. Florida ex rel. Watson, 325 U.S. 538 (1945); Allen-Bradley Local 1111, United Elec. Workers v. Wisconsin Employment Relations Bd., 315 U.S. 740 (1942).

382 U.S. 181 (1965).

'Section $2(3)$ of the NLRA provides that "the term 'employec' shall include any employee ... unless the Act explicitly states otherwise ... but shall not include 
of supervisors is not recognized and protected by federal labor legislation. 9 Hanna then filed charges with the NLRB alleging that MEBA's picketing at Duluth, Minnesota, had induced work stoppages by employees of other employers ${ }^{10}$ in violation of the section 8 (b) (4) (B) proscription against certain secondary pressures. ${ }^{11}$ The Regional Director found no violation; the General Counsel sustained this conclusion, stating that the "evidence revealed that the picketing by MEBA at the common situs . . conformed to Moore Dry Dock standards." "12 Thereafter, Hanna appealed again to the

... any individual employed as a supervisor . . . ." 61 Stat. 137 (1947), 29 U.S.C. $\S 152(3)$ (1964), amending 49 Stat. 450 (1935). (Emphasis added.)

"Section 2 (11) of the NLRA defines "supervisor" as "any individual having authority, in the interest of the employer, to hire, transfer, suspend, lay off, recall, promote, discharge, assign, reward, or discipline other employees, or responsibly to direct them or to adjust their grievances, or effectively to recommend such action, if in connection with the foregoing the exercise of such authority is not of a merely routine or clerical nature, but requires the use of independent judgment." 61 Stat. 138 (1947), 29 U.S.C. $\$ 152$ (11) (1964), amending 49 Stat. 450 (1935).

- Section 9 of the NLRA provides the necessary election machinery to enable a "majority of the employees" of an employer to select a representative for collective bargaining purposes. See 61 Stat. 143 (1947), 29 U.S.C. $\S 159$ (1964), amending 49 Stat. 453 (1935). (Emphasis added.) Since its provisions presuppose existence of workers within the act's definition of employees, collective bargaining units composed of supervisors are not included within the protection of the NLRA. While $\S 14$ of the act makes it clear that supervisors may become union members, nevertheless employers are not required to bargain collectively with individuals so classified. 61 Stat. 151 (1947), 29 U.S.C. \& 164 (1964), amending 49 Stat. 457 (1935).

${ }^{10}$ Apparently workers of other employers had refused to unload Hanna's vessels, 382 U.S. at 184, and to refuel them. Hanna Mining Co. v. District 2, Marine Eng'rs Beneficial Ass'n, 23 Wis. 2d 433, 438, 127 N.W.2d 393, 395 (1964).

11 Section 8 (b) (4) (B) provides:

"It shall be an unfair labor practice for a labor organization or its agents-

“(4) (i) to engage in, or to induce or encourage any individual employed by a person engaged in commerce or in an industry affecting commerce to engage in, a strike or a refusal in the course of his employment to use, manufacture, process, transport, or otherwise handle or work on any goods, articles, materials, or commodities or to perform any services; or (ii) to threaten, coerce, or restrain any person engaged in commerce or in an industry affecting commerce, where in either case an object thereof is-

“(B) forcing or requiring any person to cease using, selling, handling, transporting, or otherwise dealing in the products of any other producer, processor, or manufacturer, or to cease doing business with any other person, or forcing or requiring any other employer to recognize or bargain with a labor organization as the representative of his employees unless such labor organization has been certified as the representative of such employees under the provisions of section 9: Provided, That nothing contained in this clause (B) shall be construed to make unlawful, where not otherwise unlawful, any primary strike or primary picketing . . .." National Labor Relations Act, $\S 8$ (b) (4) (B), added by 61 Stat. 141 (1947), as amended, 29 U.S.C. $\$ 158$ (b) (4) (B) (1964). (Emphasis added.)

12382 U.S. at 186 n.7. In Sailors' Union of the Pacific (Moore Dry Dock), 92 
NLRB claiming that MEBA's activity constituted organizational or recognitional picketing prohibited by section $8(b)(7)$ of the NLRA. ${ }^{13}$ The Regional Director refused to file a charge; and the General Counsel sustained, holding that the "supervisory status of the licensed engineers precluded a finding that the Union's picketing and other activity was for an object proscribed by Section 8 (b) (7) . . . '" '14

Hanna then sought injunctive relief in a state court against MEBA's picketing of its ships in Superior, Wisconsin, on the ground that such picketing had an unlawful objective under state law. In affirming the lower court's dismissal of the action, the Wisconsin Supreme Court held that the pre-emption standard articulated by the Supreme Court in San Diego Bldg. Trades Council v. Garmon ${ }^{16}$ dictated that state regulation of the dispute be foreclosed because MEBA's activity was "arguably" violative of section 8 (b) (4) (B) of the NLRA. ${ }^{16}$ The Supreme Court, in an opinion which refined and seemingly modified the Garmon standard, reversed and remanded the action to the state court. ${ }^{17}$

Like Hanna, the Garmon case had presented the Court with the general problem of the extent to which Congress, by enacting

N.L.R.B. 547 (1950), the Board established guidelines to test the validity of commonsitus picketing. Generally four conditions must be met: (l) the picketing must be confined to those times when the primary employer is conducting business at the common situs; (2) he must be engaged in his normal business at the situs at that time; (3) the picketing must be limited to locations reasonably proximate to where he is transacting his business; and (4) the information conveyed by the pickets must clearly indicate that the labor dispute is with the primary employer.

${ }^{23}$ The applicable provisions of $\S 8(\mathrm{~b})(7)$ provide that "it shall be an unfair labor practice for a labor organization or its agents-

- $\cdot$.

“ (7) to picket or cause to be picketed, or threaten to picket or cause to be picketed, any employer where an object thereof is forcing or requiring an employer to recognize or bargain with a labor organization as the representative of his employees, or forcing or requiring the employees of an employer to accept or select such labor organization as their collective bargaining representative, unless such labor organization is currently certified as the representative of such employees." National Labor Relations Act, $\S 8(\mathrm{~b})(7)$, added by 73 Stat. 544 (1959), 29 U.S.C. $\S 158$ (b) (7) (1964). (Emphasis added.)

It 382 U.S. at 186 n.9.

15359 U.S. 236 (1959). Basically the Garmon standard requires that the NLRB must be given an opportunity in the first instance to regulate a dispute if the activity involved arguably is "protected by $\S 7$, or prohibited by $\S 8$ " of the National Labor Relations Act, as amended. Id. at 245 . See notes 21,30 infra and accompanying text.

${ }^{20}$ Hanna Mining Co. v. District 2, Marine Eng'rs Beneficial Ass'n, 23 Wis. 2d 433, 127 N.W.2d 393 (1964).

17382 U.S. at 194. 
the NLRA, pre-empted exercise of state power to regulate union activity. ${ }^{18}$ The problem, as stated in Garmon, was that the NLRA "leaves much to the states, though Congress has refrained from telling us how much." "19 Positing the need for general guidelines applicable to "classes of situations,"20 the Garmon majority formulated the rule that "the States as well as the federal courts must defer to the exclusive competence of the National Labor Relations Board" whenever the questioned labor activity is "arguably subject to $\S 7$ or $\S 8$ of the Act." 21 18 In Garmon the state court had awarded the employer damages under state
law for injury resulting from the union's organizational picketing. 359 U.S. at 239 .
The Supreme Court reversed, holding that the state court was precluded from regu-
lating the peaceful union activity-even by means of the indirect method of imposing
damages. Id. at 246 .

${ }^{10}$ Id. at 240 , quoting Garner v. Teamsters Union, 346 U.S. 485, 488 (1953).

30359 U.S. at 242.

31 Id. at 245 . Because of the breadth of the coverage of $\$ \$ 7-8$, commentators have generally interpreted the Garmon standard to require that the NLRB have primary jurisdiction over almost every labor activity involving interstate commerce. See, e.g., Gregory, supra note 3, at 556; McCoid, supra note 3, at 225; Note, 45 CorNel. L.Q. 384, 384-85 (1960); Note, 58 MICH. L. REv. 288, 291 (1959). Nevertheless, the Supreme Court has clearly established that pre-emption will be inoperative in some special, limited situations.

The earliest exception recognized by the Court, and one still viable today, involves conduct "deeply rooted in local feeling and responsibility." San Diego Bldg. Trades Council v. Garmon, 359 U.S. 236, 244 (1959). The reason for not precluding state action in this area is that the extent and merit of local interest are sufficient to overcome the national interest of a uniform labor policy. Thus far all of the cases encompassed by this exception have involved violence during a labor dispute. See International Union, UAW v. Russell, 356 U.S. 634 (1958); Youngdahl v. Rainfair, Inc., 355 U.S. 131 (1957); International Union, UAW v. Wisconsin Employment Relations Bd., 351 U.S. 266 (I956) (Kohler case); United Constr. Workers v. Laburnum Constr. Corp., 347 U.S. 656 (1954); Allen-Bradley Local 1111, United Elec. Workers v. Wisconsin Employment Relations Bd., 315 U.S. 740 (1942). Because the Court considers pre-emption primarily on an ad hoc basis, other possible exclusions based on the local concern rationale have not yet been revealed.

In another line of cases the Court has established that pre-emption is inapplicable in breach-of-contract suits involving $\S 301$ of the LMRA (Taft-Hartley Act), 61 Stat. 156 (1947), 29 U.S.C. \$ 185 (1964). Smith v. Evening News Ass'n, 37I U.S. 195 (1962); Atkinson v. Sinclair Ref. Co., 370 U.S. 238 (1962); Local I74, Teamsters Union v. Lucas Flour Co., 369 U.S. 95 (1962); Charles Dowd Box Co. v. Courtney, 368 U.S. 502 (1962).

A third exception exists where the activity regulated is "a merely peripheral concern" of federal labor legislation. San Diego Bldg. Trades Council v. Garmon, supra at 243. This exclusion has been applied only in International Ass'n of Machinists v. Gonzales, 356 U.S. 617 (1958), to a situation which is analogous to the breach-of-contract suits cited above and in the instant case. In Gonzales the Court permitted exercise of state power to award reinstatement and pecuniary damages to a former union member who had been unjustly expelled from membership in the international union. Argnably, there are other areas of labor-management relations which have been only of peripheral concern to Congress, but litigation has not yet exposed them. 
In many respects the Garmon standard merely reasserted previously established law by encompassing the basic principles of prior Court decisions. ${ }^{22}$ Its application precluded state interference with "clearly indicated" federal labor policy ${ }^{23}$ and reaffirmed that "courts are not primary tribunals to adjudicate" whether activity is subject to Board jurisdiction. ${ }^{24}$ It also rather clearly did not withdraw from the states "power to regulate where the activity regulated was a merely peripheral concern of the Labor Management Relations Act."25 Furthermore, conduct touching peculiarly local interests would, absent compelling congressional direction, remain within the purview of state power. ${ }^{26}$ However, the Garmon criterion also went beyond previous Court holdings by declaring pre-emption essential to facilitate national policy whenever activity is arguably proscribed by section $8 .^{27}$ Unless there exists "compelling precedent" which can be applied to "essentially undisputed facts," 28 or unless the dismissal or rejection of a complaint by the Board or General Counsel "define[s] the nature of the activity with unclouded legal significance," 29 the danger of conflict with national labor policy compels pre-emption of state regulation. By enlarging this area of labor relations reserved exclusively for Board regulation to include all activity arguably "protected by $\S 7$ or prohibited by $\S 8$, ,"30 the Court concomitantly broadened the "jurisdictional no-man's land"

Finally, in the recent case of Incres S.S. Co. v. International Maritime Workers, 372 U.S. 24 (1963), the Court held that since the NLRA does not apply to foreignflag ships employing only alien seamen, McCulloch v. Sociedad Nacional de Marineros de Honduras, 372 U.S. 10 (1963), there is no arguable federal protection or prohibition of activity involving such sailors, and a state is free to exercise its power to regulate labor controversies involving them.

22 See the summary of cases in Weber v. Anheuser-Busch, Inc., 348 U.S. 468, 474-77 (1955) and the decisions cited in Garmon, 359 U.S. at $243 \& \mathrm{n} .1$, wherein the power of the state to regulate various aspects of labor relations has been judicially denied as being inconsistent with federal policy.

23359 U.S. at 243.

s4 Id. at $244-45$.

${ }^{26} I d$. at 243 . See note 21 supra.

20359 U.S. at 244. See nate 21 supra.

27359 U.S. at 244-46. Prior to Garmon the Court had held in Garner v. Teamsters Union, 346 U.S. 485 (1953), that a state court could not regulate a labor dispute involving federally prohibited conduct by imposing a sanction inconsistent with that provided by the LMRA. In Garmon the Court interpreted Garner to extend beyond its limited fact situation and to require that states could not exercise primary jurisdiction over activity "potentially subject to the exclusive federal regulatory scheme." 359 U.S. at 247.

${ }^{28} I d$. at 246.

${ }^{28}$ Ibid. (Emphasis added.)

${ }^{30} \mathrm{Id}$. at 245. (Emphasis added.) 
wherein neither the state nor the NLRB would exert authority. Thus, if the NLRB should refuse to assert jurisdiction over conduct subject to its regulatory power, the state was nevertheless precluded from filling the jurisdictional void..$^{31}$

Four members of the Garmon court objected to the breadth of the standard promulgated by the majority opinion. ${ }^{32}$ While concurring in the result on the theory that the conduct in question arguably was protected by section $7,^{33}$ they disagreed that any activity arguably within the ambit of section 8 should be beyond the scope of permissible state regulation. ${ }^{34}$ They asserted that the

${ }^{32}$ In Guss v. Utah Labor Relations Bd., 353 U.S. 1 (1957), the Court held that a state was precluded from regulating conduct subject to federal control under the NLRA, even though the Board had previously refused to exercise its discretionary authority over the activity involved. When coupled with the Board's consistent refusal to exercise to the fullest extent its statutory jurisdiction under the NLRA, Guss occasioned a "jurisdictional no man's land" wherein labor disputes existed which the Board declined to regulate and which the states were powerless to control. This narrow area of labor relations subject to neither federal nor state regulation was broadened when the Garmon decision extended the exclusive jurisdiction of the Board. The resultant controversy impelled Congress to increase the NLRB's financial appropriation so that the Board could lower its jurisdictional standards. Later, as a more permanent means of solution, Congress passed $\S 701$ of the LaborManagement Reporting and Disclosure Act of 1959, 73 Stat. 541, 29 U.S.C. $\S 164$ (c) (1964). This section first provides tbat the Board cannot decline jurisdiction of any controversy "over which it would assert jurisdiction under the standards prevailing upon August 1, 1959." The statute further provides that states shall have power to assert jurisdiction over labor disputes which the Board has refused to mediate because they failed to meet the Board's published jurisdictional standards, or because they have an insubstantial effect on interstate commerce.

These provisions seem to cover all possible situations involving labor disputes except perhaps that advanced in a series of cases indicating that "the Board has discretionary authority to dismiss complaints for policy reasons, even though commerce is affected." Local 905, Retail Clerks Int'l Ass'n, 83 N.L.R.B. 564, 568 (1949). See Local 12, Progressive Mine Workers of America v. NLRB, 189 F.2d 1 (7th Cir.), cert. denied, 342 U.S. 868 (1951); Haleston Drug Stores, Inc. v. NLRB, 187 F.2d 418 (9th Cir.), cert. denied, 342 U.S. 815 (1951). Contra, Joliet Contractors Ass'n v. NLRB, 193 F.2d 833, 843, 814 (7th Cir. 1952), cert. denied, 346 U.S. 824 (1953). The Supreme Court has indicated approval by saying that "even when the effect of activities on interstate commerce is sufficient to enable the Board to take jurisdiction of a complaint, the Board sometimes properly declines to do so, stating that the policies of the Act would not be effectuated by its assertion of jurisdiction in that case." NLRB v. Denver Bldg. \& Constr. Trades Council, 341 U.S. 675, 684 (1951) (dictum). Arguably, this was an exception to the Board's jurisdictional standards "prevailing upon August 1, 1959"; and, as such, it would not fall within any of the enumerated categories of $\S 701$ permitting state action when the Board refuses to assert jurisdiction.

${ }^{32}$ Mr. Justice Harlan wrote the "dissenting" concurrence in which Justices Clark, Whittaker and Stewart joined. 359 U.S. at 249-54.

${ }^{33} I d$. at $249,254$.

3t "The threshold question in every labor pre-emption case is whether the conduct with respect to which a State has sought to act is, or may fairly be regarded as, federally protected activity." 359 U.S. at 250. (Emphasis added.) The minority 
majority's standard entirely deprived the states of any power to afford relief for nonviolent conduct whenever the Board declined to exercise its jurisdiction. ${ }^{35}$ Furthermore, it was argued that in cases where the Board did find that unprotected conduct was not prohibited, state redress might come too late to be effective; and that, on the other hand, if the Board should find that the activity was prohibited, its narrowly circumscribed reparation powers would often be inadequate to redress effectively those injured by that activity. ${ }^{36}$

Hanna, purporting to do no more than apply the Garmon rule, ${ }^{37}$ rested its holding that state regulation of MEBA's picketing was permissible upon two bases. The Court first found that under the Garmon standard, pre-emption should not occur. ${ }^{38}$ Since the Board had determined that Hanna's engineers were "supervisors" and therefore not "employees," 30 section 7 and much of section 8 were totally inapplicable. ${ }^{40}$ Furthermore, although section 8 (b) (4) (B)

argued that the Court's decision in Garner v. Teamsters Union, 346 U.S. 485 (1953), see note 27 supra, should be limited to its facts and that pre-emption should occur when federally prohibited activity was involved only when state damage awards or other state sanctions would be "inconsistent with federal prohibitions." 359 U.S. at 251.

The minority's position appears to be in line with earlier pre-emption cases which required an inconsistency in federal and state regulatory procedures in order to oust state jurisdiction. "The conflict lies in remedies, not rights." Garner v. Teamsters Union, supra at 498. In United Constr. Workers v. Laburnum Constr. Corp., 347 U.S. 656 (1954), the Court stated that "to the extent . . . Congress has not prescribed procedure for dealing with the consequences of tortious conduct .... there is no ground for concluding that . . . liabilities for tortious conduct have been eliminated. The care we took in the Garner case to demonstrate the existing conflict ... was, itself, a recognition that if no conflict had existed, the state procedure would have survived." Id. at 665 .

In the limited factual situation found in Hanna, the Court modified the majority position of Garmon and stated that "so far as Garmon may proceed on the view that the opportunity belongs to the Board whenever it and the State offer duplicate relief, it has limited application to the present facts." 382 U.S. at 194.

${ }^{35} 359$ U.S. at 253.

${ }^{30}$ Ibid.

37382 U.S. at 187, 194.

${ }^{38} I d$. at 192 .

${ }^{30}$ See notes 7.8 supra and accompanying text.

${ }^{40}$ National Labor Relations Act, § 2, 61 Stat. 137 (1947), 29 U.S.C. § 152 (1964), amending 49 Stat. 450 (1935), defines "employee," "supervisor" and other terms frequently used in the act. The definitions are general in nature and are applicable whenever the terms are employed. In Hanna the Board interpreted the definitions of "employee" and "supervisor" to be mutually exclusive categories, see note 7 supra and accompanying text, and ruled that Hanna's engineers were supervisors. See note 8 supra and accompanying text. Therefore, the workers involved were "non-employees" for all purposes under the NLRA and its amendments. This result meant that MEBA's activity could not be "protected by $\S 7$," for $\$ 7$ provides that 
does in part apply to activities involving supervisors, ${ }^{41}$ the Court held that the General Counsel's refusal to charge MEBA with an infraction of its provisions "squarely define[d] the nature of the [picketing] activity"42 as being outside the proscription of section 8 .

Having thus applied the Garmon criteria to the existent facts and concluded that pre-emption was inoperative, the Court could have terminated its inquiry. However, it ventured to advance an alternative rationale for allowing state action in the instant case by holding that "even if a $\S 8(\mathrm{~b})(4)$ (B) violation were present," state regulation would be permissible, ${ }^{43}$ for the "greatest threat against which the Garmon doctrine guards" is "a State's prohibition of activity that the Act indicates must remain unhampered." 44 Since the Board had previously determined that the engineers sought to be organized were "outside the regime of the Act," 45 there could be no such protected conduct present in Hanna; and exercise of state power was not pre-empted.

In applying the Garmon test to the factual situation in Hanna, the Court recognized a useful procedure which a labor practitioner can utilize to establish the "unclouded legal significance"46 of activity in order to avoid pre-emption in state and federal courts. The Court ruled that the language of Garmon, indicating that refusal of the General Counsel to issue a complaint was not sufficiently dispositive of the nature of the conduct to permit state regulation, ${ }^{47}$ "allows more than one interpretation, but we take it not to apply to those refusals of the General Counsel which are illuminated by explanations that do squarely define the nature of the activity." 48

\footnotetext{
"employees shall have the right to self-organization . . . 61 Stat. 140 (1947), 29 U.S.C. $\$ 157$ (1964), amending 49 Stat. 452 (1935). (Emphasis added.) Similarly, those parts of $\S 8$ using the term "employees" were inapplicable in Hanna.

"Those subparts of the section which do not use the term "employees," but rather "any individual" or "any person," are available to regulate a labor dispute involving only supervisors or other non-employees, if there is jurisdiction in other respects. See statutory text, note 11 supra.

12382 U.S. at 192.

13 Id. at 192-93.

"Id. at 193 .

"Ibid.

10 See text accompanying note 29 supra.

"See note 52 infra and accompanying text.

* 382 U.S. at 191-92. This holding is appropriate in light of the organizational structure of the NLRB as established by Congress, for $\S 3$ (d) of the NLRA provides that the General Counsel "shall have final authority, on behalf of the Board, in respect of the investigation of charges and issuance of complaints . . ." 61 Stat. 139 (1947), as amended, 29 U.S.C. $\S 153($ d) (1964) amending 49 Stat. 452 (1935).
} 
Thus Board rulings, General Counsel determinations, or a combination of the two will suffice to establish that activity is not arguably "protected by $\S 7$, or prohibited by $\S 8$. . 49

In Hanna this clarification permitted the Court to hold that MEBA's "unprotected" activity was also not "prohibited," for the General Counsel had set forth definitive reasons for refusing to charge MEBA with a section 8 violation. ${ }^{50}$ Furthermore, the Court's approach avoided a possible "jurisdictional no man's land," 51 for a more literal application of the Garmon rule would have precluded exercise of state power and subjected MEBA's activity to neither federal nor state regulation, ${ }^{52}$ thus leaving self-help and the play

Furthermore, the courts have held that judicial review of the General Counsel's exercise of discretion with respect to the issuance of complaints is impermissible. Hourihan v. NLRB, 201 F.2d 187 (D.C. Cir. 1952), cert. denied, 345 U.S. 930 (1953); Lincourt v. NLRB, 170 F.2d 306 (Ist Cir. 1948).

40 Thus, it appears that here, as in other areas of labor law where pre-emption is at issue, the first procedural step is to file a complaint with the NLRB. Since time is usually of the essence in a labor dispute, it is advantageous to receive all rulings from the Board and General Counsel as quickly as possible. Allegations frequently should be phrased in terms of alternatives. For example, if there is doubt about the status of the workers involved, it may be initially asserted that they are not "employees" under the act; an adverse determination on this question may be guarded against by alleging in the alternative that the activities involved are violative of all the arguably applicable provisions of the act.

There may be exceptions to these rules, however. Since such alternative allegations may retard the efficiency with which a petition will be handled, both by the General Counsel's office and by the Board, it may be useful to do as Hanna did and petition on a piecemeal basis. For example, if it appears very likely that the workers are "non-employees," it may be desirable to obtain such a determination in the most expeditious manner possible; for thereafter a state court may be approached for relief on the basis of the Hanna rationale.

so See notes 12-14 supra and accompanying text. The General Counsel ruled that there was no $\S 8(\mathrm{~b})(4)(B)$ violation with respect to the picketing at Duluth, Minnesota, but the picketing in issue occurred in Superior, Wisconsin. However, "the Regional Director is said to have conducted an investigation in Superior as well as in Duluth, and the General Counsel's letter on the $\S 8$ (b) (4) (B) charge appeared to state that activity at the sites other than Duluth also did not violate the Act." 382 U.S. at 192. Also, Hanna alleged and offered to prove that the essential aspects of the picketing at the two sites were identical, and the Court accepted its allegations as uncontradicted with the proof to be offered upon hearing on remand to the state court. Id. at 191-92.

"See note 31 supra and accompanying text. The Court was well aware of the possible jurisdictional void which would have resulted, for $\mathrm{Mr}$. Justice Brennan alluded to it in his concurring opinion. 382 U.S. at 196.

${ }^{62}$ The actual language of the Court in Garmon was that "the Board may also fail to determine the status of the disputed conduct by declining to assert jurisdiction, or by refusal of the General Counsel to file a charge, or by adopting some other disposition which does not define the nature of the activity with unclouded legal significance .... It follows that the failure of the Board to define the legal significance under the Act of a particular activity does not give the States the power to act." 359 U.S. at $245-46$.

The Wisconsin Supreme Court, without any discussion of other possible inter- 
of economic forces to arbitrate and resolve the dispute..$^{53}$ However, since it is the declared policy of the General Counsel always to enunciate his reasons for denying issuance of a complaint, ${ }^{54}$ the Court effectively diminished the jurisdictional void that would have resulted from state regulation being precluded whenever the General Counsel refused to file a charge.

The Hanna opinion, however, has further implications for the labor practitioner. In its alternative rationale the Court held that since MEBA's activity was not "protected by $\S 7$," state regulation of it was permissible even if the picketing was "prohibited by $\$$ 8."'55 In this manner the Court indicated that when the Board rules

pretations, held that the clear import of the language was that a denial by the General Counsel to issue a complaint precluded state regulation. 23 Wis. 2d at $445-46,127$ N.W.2d at 399.

${ }^{53}$ Pre-emption would have precluded state action, and lack of jurisdiction would have prevented Board regulation under $\S 8(\mathrm{~b})(7)$. See notes 14, 30-31 supra and accompanying text.

In some instances the General Counsel may deny issuance of a complaint even though he believes that there has been an unfair labor practice committed. For example, his investigation may show that the jurisdictional standards of the Board are not met or that substantial effect on interstate commerce is not involved. Therefore, refusal to issue a charge does not affirmatively establish that the activity is free from illegality, and it may be thought appropriate to permit state regulation after the General Counsel has refused to issue a complaint in order to prevent a jurisdictional void.

The case law, however, has not as yet reached this conclusion. Garmon rejected the notion that the state could intervene if the Board declined to exercise jurisdiction. Hanna modifies this position only when the Board or the General Counsel clearly indicates that federal law is not applicable to a given dispute. Of course, congressional dissatisfaction with the judicially and administratively created jurisdictional gap was manifested by the enactment of $\S 701$ of the Labor-Management Reporting and Disclosure Act of 1959, which virtually eliminated the "no man's land" between the application of federal and state authority. See note 31 supra.

sc "When the General Counsel denies an appeal from a Regional Director's refusal to issue a complaint, he notifies the parties in writing of the reasons for his action." Letter from Dominick L. Manoli, Associate General Counsel, National Labor Relations Board, to the Duke Law Journal, March 7, 1966.

A logical extension of the Court's holding in Hanna that refusal of the General Counsel to file a charge is sufficiently dispositive of the nature of the conduct involved to avoid pre-emption arises when the General Counsel denies the complainant's appeal and indicates that he is doing so on the basis of the Regional Director's findings of fact. The present General Counsel has testified that whenever a "regional director determines a complaint should not issue, he is required to so advise the charging party in writing, stating the reasons for his action, and informing the charging party of his right to appeal to the General Counsel." Hearings Before the Special Subcommittee on Labor of the Fouse Committee on Education and Labor, 89th Cong., 2d Sess. 11 (1966). In light of this organizational structure the General Counsel's affirmance of the Regional Director's finding should be interpreted as an adoption of the Regional Director's reasoning and statement(s), thus defining the nature of the activity in question.

ธะ 382 U.S. at 192.93. 
that the workers involved in a labor dispute are outside the scope of federal protection, the "prohibited by $\S 8$ " part of the Garmon standard becomes superfluous; and state courts have concurrent jurisdiction with the NLRB to regulate the controversy and issue injunctions..$^{56}$

It is highly unlikely that any state court would have anticipated this alternative rationale and enjoined MEBA's conduct after the Board's ruling on petition one that only supervisors were sought to be organized in the Hanna situation. One reason for this conclusion is that the Supreme Court had previously held in Marine Eng'rs Beneficial Ass'n v. Interlake S.S. Co. ${ }^{57}$ that when interpretation of the act is involved, a state court cannot adjudicate the issues upon which its own jurisdiction depends. Furthermore, by affording equal emphasis to the disjunctive parts of the protected-prohibited standard, Court decisions in the interim period between Garmon and Hanna had implicitly rejected the Garmon minority's argument that pre-emption should normally occur only when there is arguably "federally protected activity" 58 involved.50

Nevertheless, Hanna is not necessarily inconsistent either with Interlake or with Garmon, for only supervisors were present in

${ }^{50}$ Ibid. It should be pointed out, however, that the actual circumstances under which the Board and state courts would have "concurrent jurisdiction" may be relatively rare. In Hanna itself the General Counsel determined that the union had not violated the provisions of $\$ 8$. Conceivably, however, a situation could arise in which, for example, a "labor organization" may attempt to organize supervisors but in the process may go beyond "primary" picketing and thus violate $\S 8$ (b) (4) (B) by bringing unlawful secondary pressure in contravention of the Board's common situs (Moore Dry Dock) regulations. Sce note I2 supra and accompanying text. Presumably in this circumstance the state could enjoin the picketing, even though the NLRB could likewise act, on the theory that federal interests relating to protected activity are not existent. See ibid.

${ }^{57} 370$ U.S. 173 (1962). In Interlake the employer received state injunctive relief against picketing by MEBA on the ground that the union's activity was violative of state law. In rejecting MEBA's pre-emption arguments, the state courts held that there was no Board jurisdiction under federal labor legislation, for MEBA was not a "labor organization" as defined in section $2(5)$ of the NLRA. See note 61 infra. The Supreme Court reversed, holding that since the Board had, in other contexts, previously determined that MEBA was a "Iabor organization," the dispute was arguably within the jurisdiction of the NLRB. 370 U.S. at 182-83. In bypassing the Board and proceeding directly to the state court for relief, the employer tended to nullify the role of the expert administrative agency established by Congress by allowing the state court to usurp the Board's primary jurisdiction to interpret and apply the provisions of the NLRA.

${ }^{58}$ Sce note 34 supra.

6s See, e.g., Liner v. Jafco, Inc., 375 U.S. 301 (1964); Local 207, Int'l Ass'n of Bridge Workers v. Perko, 373 U.S. 701 (1963); Local 100, United Ass'n of Journeymen v. Borden, 373 U.S. 690 (1963); Local 438, Constr. Union v. Curry, 371 U.S. 542 (1963). 
Hanna. ${ }^{60}$ By excluding them from the definition of "employees," Congress had indicated that they should not be encouraged to engage in organizational activities. ${ }^{61}$ In withdrawing the protection of section 7 from supervisors, however, Congress apparently unintentionally and quite anomalously also exempted them and the labor organizations to which they belong from at least some of the proscriptions of section $8 .{ }^{62}$ In Hanna this congressional oversight

"However, this is not to say that there is not language in Garmon which is inconsistent with the Court's subsequent reasoning in Hanna. For example, in Garmon the Court said that "the governing consideration is that to allow the States to control activities that are potentially subject to federal regulation involves too great a danger of conflict with national labor policy." 359 U.S. at 246.

"Supervisors cannot organize themselves into a "Iabor organization" to receive protection under the act, for a labor organization is defined as "any organization of any kind, or any agency or employee representation committee or plan, in which employees participate and which exists for the purpose, in whole or in part, of dealing with employers concerning grievances, labor disputes, wages, rates of pay, hours of employment, or conditions of work." National Labor Relations Act, § 2 (5), 61 Stat. 138 (1947), 29 U.S.C. $\$ 152(5)$ (1964) (re-enactment of 49 Stat. 450 (1935)). (Emphasis added)

Although supervisors are not prevented from joining labor organizations (that is, unions having at least two "employees" as members), see note 9 supra, such membership apparently will be of little practical value to them, for their activities within the labor organization will not be protected under the act. Conceivably, a labor organization comprised of both "employees" and "supervisors" could engage in activity which would be protected if it were on behalf of its "employee" members but would be unprotected if it were on behalf of its "supervisor" members. Cf. National Marine Eng'rs Beneficial Ass'n v. NLRB, 274 F.2d 167 (2d Cir. 1960).

On the other hand, it has clearly been held that, as to the proscriptions of $\S 8$ (b), a "labor organization" is bound even if its organizing activity is directed solely toward "supervisors" or is otherwise acting in behalf of "non-employees." See International Organization of Masters v. NLRB, 351 F.2d 771, 775 (D.C. Cir. 1965); National Marine Eng'rs Beneficial Ass'n v. NLRB, supra at 173.

'See 382 U.S. at 189-90. MEBA contended that Congress had evinced a solicitous attitude toward supervisors' organizational activities by concurrently eliminating supervisors from the definition of employees and providing that they should not be prohibited from joining labor organizations. See National Labor Relations Act, \$14 (a), 61 Stat. 151 (1947), 29 U.S.C. $\$ 164$ (a) (1964), amending 49 Stat. 457 (1935); note 8 supra. The Court rejected the argument that by this action Congress had established a policy of laissez-faire toward supervisory personnel, thereby precluding both Board and state regulation of peaceful organizational efforts in general and of primary picketing in particular. 382 U.S. at 189. Cf. Local 20, Teamsters Union v. Morton, 377 U.S. 252 (1964). Indeed, legislative history indicated that "Congress' propelling intention was to relieve employers from any compulsion under the Act and under state law to countenance or bargain with any union of supervisory cinployees." 382 U.S. at 189, citing S. REP. No. 105, 80th Cong., 1st Sess. 5 (1947); H.R. REP. No. 245, 80th Cong., Ist Sess. 13-17 (1947).

Thus when Congress excluded supervisors from the coverage of $\S 7$, it "clearly sought to shield employers from the collective activities of supervisors, not to deprive [employers] . . of federal protection." Note, 47 MiNN. L. REv. 656, 659 (1963). However, since all those provisions of $\S 8$ using the term "employees" became inapplicable and because $\S 8$ itself is directed against "labor organization[s]" in which "employees" must "participate," see note 61 supra, supervisors and the labor 
occasioned a lack of Board jurisdiction to regulate MEBA's activity under the appropriate federal provision, section $8(\mathrm{~b})(7) .{ }^{63}$ Thus the Board could neither carry out Congress' negative attitude toward MEBA's organizational-recognitional picketing nor "afford complete protection to the legitimate interests advanced by the State."64

Therefore, since implementation of congressional "intent" is the ostensible reason for the existence of the pre-emption doctrine, exercise of state power should not be pre-empted when the workers involved "are outside the regime of the Act,"68 for such regulation will only further Congress' implicitly declared attitude toward "nonemployee" organizational efforts. Thus permitting state regulation after the Board determination in Hanna that MEBA's picketing was not "federally protected activity" was both justifiable to achieve an equitable result and requisite to achieve the congressional purpose. This qualification of the Garmon test will be appropriate, however, only when no "employees" have engaged in the questioned activity or are sought to be organized or when some other factor exists which renders the Board powerless to fulfill congressional objectives by affording an effective remedy, thus clearly indicating that there will be no conflict between state and Board action. Only in these limited instances will state regulation of federally proscribed activity be consonant with congressional designs.

In Hanna the Board's determination that no employees were involved to receive the benefit of federal protection established that there was only limited jurisdiction under federal labor legislation; ${ }^{B T}$

organizations to which they belong were also freed from at least some of the burdens of compliance with the LMRA. Thus the Board has jurisdiction to prohibit union activity with respect to supervisors which would constitute an unfair labor practice if performed in relation to "employees" only if the practice has been fortuitously proscribed in the LMRA without using the term "employees." Worse yet, an association composed solely of supervisors may be entirely free of the prohibitions of $\S 8$. See National Marine Eng'rs Beneficial Ass'n, supra note 61, at 173 (dictum); Note, 47 MINN. L. REv. 656, 659 (1963); note 11 supra.

"section 8 (b) (7) uses the term "employees." See note 13 supra.

The Court indicated in dictum that but for the fact that supervisors were in. volved in Hanna, MEBA's picketing violated $\S 8$ (b) (7). 382 U.S. at 190, 194 \& n.16.

- Id. at 194.

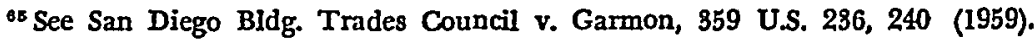

See note 45 supra and accompanying text.

${ }^{67}$ See notes 40.42, 68-64 supra and accompanying text.

In this respect Hanna is analogous to the exception to pre-emption set forth in Incres S.S. Co. v. International Maritime Workers, 372 U.S. 24 (1968), where it was held that there was no NLRA jurisdiction over foreign-flag ships employing alien 
that Congress had implicitly indicated a negative attitude toward unionization of the workers involved; ${ }^{68}$ and that exercise of state power could not adversely affect national labor policy. ${ }^{69}$ In this fact situation national interest in a uniform labor policy was minimal. ${ }^{70}$ Although the state's interest in curbing MEBA's picketing was not exceedingly high, ${ }^{71}$ the nature of the activity dictated that it should be regulated. Since only state law remained available, the Court found pre-emption inappropriate. In so doing, it correctly perceived congressional intent and justifiably allowed exercise of state power in the instant case.

seamen. See note 21 supra. Arguably, Hanna merely extends this exception to the situation where there is only limited jurisdiction under the act.

OB 382 U.S. at $189-90$.

${ }^{\circ}$ Id. at 192.93.

${ }^{70}$ Hanna is similar to International Ass'n of Machinists v. Gonzales, 356 U.S. 617 (1958), in regard to the degree of national interest involved. As was true of the activity in Gonzales, see note 21 supra, a labor dispute involving supervisors is "a merely peripheral concern" of the NLRA, and as such it can be regulated by state action.

Mr. Justice Brennan based his concurrence on the notion that "only incidental [that is, the secondary] aspects of picketing were arguably subject to federal power" in Hanna. 382 U.S. at 195-96. He emphasized the proviso to $\S 8$ (b) (4) (B), which is, "nothing in this clause (B) shall be construed to make unlawful, where not otherwise unlawful, any primary strike or picketing." "Id. at 195. (Emphasis in original.) This was intexpreted to mean that Congress had indicated that a state can regulate the primary aspects of supervisory picketing but not its secondary incidents, which are arguably governed by $\S 8$ (b) (4) (B). As a practical matter, however, the Justice acknowledged that regulation of the primary element necessarily affected the picketing considered in its secondary aspect.

${ }^{71}$ Although work stoppages were occasioned by MEBA's activities, see note 10 supra, at all times the picketing was peaceful. The peculiar, highly local interest of keeping the peace and protecting citizens from physical harm that gives rise to permitting state regulation of violence in connection with labor dispute, see note 21 supra, was absent in Hanna. 